Prace Filologiczne. Literaturoznawstwo 11(14) 2021

ISSN 2084-6045

e-ISSN 2658-2503

Creative Commons: Uznanie autorstwa 3.0 PL (CC BY)

DOI: $10.32798 /$ pflit.557

\title{
MASZYNA DO PISANIA, MASZYNA DO ZAPAMIĘTYWANIA. ANTONELLI ANEDDY ZMAGANIA Z HISTORIA - Z PERSPEKTYWY TŁUMACZA
}

\author{
A Typewriter, a Memory Writer. \\ Antonella Anedda's Struggle with History - Translator's Perspective
}

OLGA PŁASZCZEWSKA

Uniwersytet Jagielloński w Krakowie, Polska

E-mail: olga.plaszczewska@uj.edu.pl

https://orcid.org/0000-0002-0814-2762

Abstract

This interpretative essay concerns the concept of time landmarks reflected in contemporary Italian poetry an example of which makes Antonella Anedda's poem Macchina [Machine]. The poem is analysed to explore figurative meanings of 'machines' depicted in the text such as battering rams, typewriters, or computers as the artefacts of historical interest. These figurative meanings are interpreted in the context of memory and history and their associations with literature. As the conclusion of this essay the author presents her own Polish translation of the poem Macchina.

Keywords: Antonella Anedda, time landmarks, contemporary Italian poetry, typewriter and computer as metaphors, history, memory

\section{Streszczenie}

Artykuł to przyczynek interpretacyjny, poświęcony lekturze wiersza Antonelli Aneddy Macchina (Maszyna). Komentarz tłumacza dotyczy metaforycznych znaczeń maszyn (do pisania, komputera, taranu) w kontekście związków historii i pamięci z literaturą. Podsumowaniem artykułu jest prezentacja autorskiego przekładu utworu Aneddy na język polski.

Słowa kluczowe: Antonella Anedda, cezury, współczesna poezja włoska, maszyna do pisania i komputer jako metafory, historia, pamięć 
Zachęta do refleksji na temat cezur, sposobów ich traktowania i definiowania w literaturoznawstwie, na temat ograniczeń i możliwości „stosowania kategorii delimitacyjnych i różnicujących oraz o narzędziach wykorzystywanych przez specjalistów zajmujących się odmiennymi etapami rozwoju literatury" ${ }^{1}$ prowokuje także do zadania pytania o to, czy świadomość tak rozumianych granic występuje (i jak się objawia) również w literaturze współczesnej. Piśmiennictwo od starożytności używa podstawowych kategorii delimitacyjnych, takich jak naturalne „początek” i „koniec”, określa pory dnia, w których toczy się akcja. Literatura klasyczna operuje pojęciami i częściami składowymi dzieła, które zakładają jego etapowy przebieg (od prologu do zakończenia). Cechą literatury postmodernistycznej jest podobno zatarcie schematów gatunkowych gwarantujących tego rodzaju etapowość, zaburzenie logiki zdarzeń, zanik linearnego opisu². Jednak wszystkie te cechy zaobserwować można już w twórczości Lawrence'a Sterne'a, począwszy od jego Podróży sentymentalnej.

Cezura to jednak nie tylko granica między początkiem a końcem (czyjegoś działania, obecności literackiej mody, aktywności, sposobu rozumienia kultury, nurtu teoretycznoliterackiego), ale również zjawisko, które samo staje się przedmiotem refleksji artystycznej. Szczególnie interesująca wydaje się sytuacja, kiedy uwaga obserwatora skupia się nie na samym procesie ustawania bądź przerywania się jakiegoś fenomenu, ale na obiektach materialnych ${ }^{3}$, których obecność lub nieobecność wyznacza granice jego trwania.

W wydanym w 2018 r. zbiorze wierszy pt. Historiae dotyka tego problemu Antonella Anedda, współczesna (ur. w 1958 r.) poetka włoska, zamieszkała w Rzymie ${ }^{4}$ (co - ze względu na różnice kulturowe i mentalnościowe pomiędzy

${ }^{1}$ Z przesłania Redakcji „Prac Filologicznych. Literaturoznawstwo” do numeru poświęconego cezurom.

${ }^{2}$ Cf. G. Milani, Postmoderno, w: G. Milani, M. Pepe, Dizionario di arte e letteratura. Teorie. Movimenti. Generi. Tecniche. Materiali, Milano 2003, s. 480-482.

${ }^{3}$ Co charakterystyczne, o ile zmieniają się przedmioty i narzędzia materialne, których używa humanista, o tyle metody (czyli narzędzia), jakimi się posługuje, w gruncie rzeczy nie ulegają wielkim zmianom od XIV w.: sztuka retoryki, umiejętność analizy i interpretacji tekstu służą uczonym do dziś, mimo że teoria literatury chętnie posługuje się nowymi terminami (często na określenie dawnych zjawisk, cf. P. Boitani, E. Di Rocco, Guida allo studio delle letterature comparate, Roma-Bari 2013, Kindle e-book, loc. 195/10218). Natomiast zamiast ołówka, pióra, papieru lub pergaminu pojawiają się stopniowo inne urządzenia: wieczne pióra, maszyny do pisania, komputery, cf. E. Gardiner, R. G. Musto, The Digital Humanities. A Primer for Students and Scholars, Cambridge 2015, s. 67 i n.

${ }^{4}$ Jarosław Mikołajewski (cf. idem, W szczelinie między czuwaniem a snem. Sto dziesięć wierszy włoskich poetów współczesnych, tłum. J. Mikołajewski, Kraków-Budapeszt-Syrakuzy 2019, s. 9), określa ją następująco: „Urodziła się (1958) i mieszka w Rzymie”, natomiast na kartach Rzymskiej komedii próbuje zdefiniować jej miejsce wśród żyjących włoskich autorów, wymieniając jej nazwisko obok nazwiska Valeria Magrellego. Cf. J. Mikołajewski, Rzymska komedia, Warszawa 2011, s. 262-263. 
poszczególnymi regionami Włoch oraz ich ośrodkami intelektualnymi, a także wyraźną w jej twórczości romanitas, zanurzenie w tradycji łacińskiej głębsze niż tylko dzisiejsza romanità - wydaje się znaczące). Anedda to autorka kilku tomików poezji i kilku książek prozą, wykładowca na Università della Svizzera Italiana w Lugano, tłumaczka poezji klasycznej i współczesnej, miłośniczka twórczości Zbigniewa Herberta, znana jako piewczyni przedmiotów codziennego użytku, które nadają jej oszczędnej w środki artystyczne i surowej pod względem języka poezji „una netta concretezza di dettagli [jasną konkretność szczegółów]”. Tytuł wspomnianego zbioru nawiązuje do antycznej tradycji kronik i annałów, w eleganckim i wyznaczonym normami retoryki stylu opisujących zdarzenia zmieniające bieg dziejów jednostek i zbiorowości. Krytycy - zgodnie z pierwotną intencją autorki - często odczytują ten cykl poezji jako bezpośrednią reakcję literacką na dramat uchodźców z Afryki, usiłujących dostać się do Europy drogą morską i trafiających zwykle na włoskie wyspy ${ }^{6}$, z najbardziej znaną dzięki mediom i publicystyce Lampedusą. Jednak Historiae Aneddy są czymś więcej niż poezją społecznie zaangażowaną ${ }^{7}$. Poruszające siłą artystycznego wyrazu, grą stylistyczną (wykorzystanie elementów języka historiografii w utworach par excellence lirycznych, zastosowanie mowy potocznej w połaczeniu z wyrafinowanymi metaforami) stanowią godna uwagi i niecodzienną (w dobie postrzegania dziejów przede wszystkim przez pryzmat ich potencjalnego przebiegu alternatywnego) analizę praw oraz mechanizmów rządzących historią.

Na cezurę niedostrzeżoną, zmianę, która zaszła niepostrzeżenie i bez hałasu, kieruje uwagę wiersz o charakterystycznym dla poetyki Aneddy, pozbawionym rodzajnika ${ }^{8}$ tytule Macchina. Translatorska interpretacja tego utworu wydaje się dobrym pretekstem, by na problem cezur spojrzeć przez pryzmat poezji i metafor, w których pojawiają się reminiscencje rzeczywistych lub imaginowanych przełomów w dziejach ludzkości.

\section{Antonella Anedda, Macchina}

Le dita sulla tastiera del computer schioccano

- solo più leggermente -

come un tempo la macchina per scrivere.

${ }^{5}$ Cf. E. Testa, Antonella Anedda, w: Dopo la lirica. Poeti italiani 1960-2000, red. idem, Torino 2005, s. 401-402.

${ }^{6}$ Cf. M. G. Calandrone, Antonella Anedda chiara come una pietra, http://www.mariagrazia calandrone.it/index.php?option $=$ com_content $\&$ view $=$ article $\&$ id $=604$ :antonella-anedda-historia $\&$ catid $=18 \&$ Itemid $=162$ (d.d. 30.03 .2020 ).

${ }^{7}$ Cf. D. Sinfonico, Poesia come sintesi dei saperi. Historiae di Anedda, 13.10.2018, https://www. labalenabianca.com/2018/11/13/21440/ (d.d. 30.03.2020).

${ }^{8}$ Co stanowi charakterystyczną cechę jej poezji, cf. E. Testa, op. cit., s. 402. 
Era bello quel nome: macchina, ancora meglio quando senza la c ritorna machina. Impalcatura per un dio o un assedio, ariete per abbattere le mura.

Rimandava a un arto di ferro, un ordigno e un artiglio che ubbidiva al cervello.

Eppure non ha senso rimpiangere il passato, provare nostalgia per quello che crediamo di essere stati.

Ogni sette anni si rinnovano le cellule: adesso siamo chi non eravamo. Anche vivendo - lo dimentichiamo restiamo in carica per poco ${ }^{9}$.

Niejednoznaczny jest sam tytuł wiersza: macchina może oznaczać każde właściwie urządzenie mechaniczne ${ }^{10}$, z samochodem włącznie. Sytuuje też tekst Aneddy w kontekście utworów poetyckich, w których przedmioty związane $\mathrm{z}$ techniczną rejestracją procesu twórczego i odtwarzaniem jego rezultatów (jak patefon, magnetofon albo odtwarzacz płyt kompaktowych) „stają się przedmiotem obserwacji, namysłu, punktem wyjścia dla metafor i źródłem symbolicznych sensów"11. Klawiatura komputerowa z pierwszego wersu zawęża pole skojarzeń i wskazuje jedną z możliwości (osadza też sytuację liryczną w czasie: scena rozgrywa się wtedy, kiedy pisanie na komputerze stanowi praktykę codzienną ${ }^{12}$ ), dopiero $\mathrm{w}$ trzecim wierszu ujawniona zostaje tożsamość urządzenia. To maszyna do pisania, której wyobrażenie zbudowane jest $\mathrm{z}$ serii obrazów, odsyłających do różnych słownikowych znaczeń terminu macchina. Oba narzędzia należą do repertorium motywów obiegowych literatury powszechnej. Na przełomie lat pięćdziesiątych i sześćdziesiątych XX w. maszyna do pisania pojawia się w poezji beatników, natomiast różnego rodzaju bardziej wyrafinowanych i w różnym stopniu zmechanizowanych „piszących maszyn”

${ }^{9}$ A. Anedda, Macchina, w: eadem, Historiae, Torino 2018, s. 22.

${ }^{10}$ Cf. [hasło:] Macchina, w: G. Devoto, G. C. Oli, Il dizionario della lingua italiana, Firenze 1995, s. 1119; N. Zingarelli, Lo Zingarelli 2019. Vocabolario della lingua italiana, red. M. Canella, B. Lazzarini, Bologna 2018 (Versione 1.45, iPhone). Dalsze odniesienia znaczeniowe, jeśli nie podano inaczej - na podstawie tych źródeł.

${ }^{11}$ Cf. I. Puchalska, Maszyny muzyczne, maszyny poetyczne: urządzenia i nośniki fonograficzne $w$ wierszach poetów polskich $X X$ wieku, ,Rocznik Komparatystyczny/Comparative Yearbook/ Komparatistisches Jahrbuch" 2016, nr 7, s. 159-160.

${ }^{12}$ Za początek „ery komputerowej” dla humanistyki uważa się rok 1949, kiedy jezuita o. Roberto Busa przekonał dyrektora IBM, Thomasa J. Watsona, do opracowania i stworzenia maszynowego indeksu i korpusu dzieł św. Tomasza z Akwinu, cf. Ch. van den Heuvel, Historical Roots of Information Sciences and the Making of e-Humanities, w: Making of Humanities, t. 3: Modern Humanities, red. R. Bod, J. Maat, Th. Weststeijn, Amsterdam 2014, s. 473. 
nie brakuje, jak dowodzi Brian McHale, w pisarstwie postmodernistycznym, między innymi u Williama Borroughsa, Russela Hobana (Medusa Frequency, 1987), Umberta Eco (Wahadto Foucaulta, 1988), Thomasa Pynchona (Vineland, 1990) i Christine Brooke-Rose (Amalgamemnon, 1984; Textermination, 1991) ${ }^{13}$. W dwudziestowiecznej prozie polskiej, dodajmy, podobnie: u Stanisława Lema („elektrorybałt” w Cyberiadzie).

Anedda wnosi do tego repertorium nową wartość. W jej utworze każde z urządzeń okazuje się również znakiem kolejnych faz rozwoju historii: znaczenia wyrazu ulegają kolejnym aktualizacjom, kiedy ich desygnaty przestają istnieć lub pełnić tradycyjnie przypisywaną rolę. Wieloznaczność pojęcia macchina i towarzyszących mu odniesień, wokół których konstruowana jest główna metafora wiersza, stanowi wyzwanie dla tłumacza. Przykładowo słowo impalcatura, poza podstawowym sensem, wywołuje także dźwiękowe skojarzenia z terminem palco (scena), ale może oznaczać równie dobrze szafot jak strukturę wewnętrzną (organizacji lub państwa). Czym jest dla bóstwa i oblężenia? Można domyślić się, że rusztowaniem, tym bardziej że wyrazem machina określano wszelkiego rodzaju maszyny oblężnicze, co sugeruje proponowany w tekście zapis nawią-

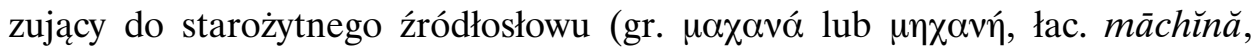
machinae). Ten sam termin opisywał później także dźwigi służące do transportu figur świętych podczas procesji w trakcie wielkich uroczystości kościelnych. W przekładzie grę różnorodnych znaczeń trzeba uobecnić mniej wyrafinowaną aluzją, wykorzystując różnicę semantyczną między pojęciami maszyna a machina (zakres znaczeniowy słowa łacińskiego jest szerszy od polskiego), również związaną z warstwą brzmieniową wyrazów. W mniejszym stopniu wywołuje ona skojarzenia historyczne, gdyż oba słowa występują we współczesnej polszczyźnie. W języku włoskim macchina to - jak często w łacinie - 'maszyneria teatralna' (system dźwigów i zapadni pozwalający na zmianę dekoracji). W tekście Aneddy te znaczenia się nawarstwiają, wywołują skojarzenia zarówno ze scenicznym efektem deus ex machina, jak i ze sferą sacrum, traktowaną (dzięki użyciu rodzajnika nieokreślonego un i zapisu rzeczownika dio - 'bóg, bóstwo' - małą literą) jako przynależna do przeszłości, a usytuowaną poza kontekstem chrystianizmu i monoteizmu w ogóle (un dio sugeruje kontekst wielobóstwa), czyli sprowadzoną do świeckiego wymiaru profanum ${ }^{14}$, w którym odwołanie do bóstwa oznacza

${ }^{13}$ Cf. B. McHale, Poezja jako proteza, thum. A. Rogulska, „Techsty. Magazyn” 2014, nr 9 (1), http://www.techsty.art.pl/m9/b_mchale_poezja_jako_proteza.html (d.d. 15.04.2020).

${ }^{14} \mathrm{Na}$ marginesie warto zauważyć, że krąg skojarzeń desakralizacyjnych wywołuje maszyna do pisania w poemacie Mescaline Allana Ginsberga (1926-1997), gdzie powtórzenie siedmiokrotnie słowa bóg, zapisanego małą literą, imituje stukot klawiszy i staje się metaforą bezsensu ludzkiej egzystencji wobec bliżej nieokreślonych Niebios: „god god god god god god god the Lone Ranger / the rhythm of the typewriter // What can I do to Heaven by pounding on Typewriter" 
zwrot ku przeszłości. Z kolei militarny kontekst machinarium konkretyzuje się w obrazie z siódmego wersu (,ariete per abbattere le mura”). Ariete ('baran') to nie tylko nazwa jednego ze znaków zodiaku, ale techniczne określenie taranu oblężniczego, wywodzące się od kształtu żelaznego okucia na przodzie belki uderzającej, modelowanego na wzór baraniego łba ${ }^{15}$. To zatem kolejny termin odsyłający do przedmiotów, których wyjście z użycia pociągnęło za sobą archaizację nazwy i rozmycie się jej znaczenia. Wers ósmy rozpoczyna się od czasownika w czasie przeszłym niedokonanym (imperfetto). Rimandare znaczy w tym kontekście 'odsyłać do, kojarzyć się z, przywodzić na myśl'. Rimandava może odnosić się zarówno do pojęcia machina, jak i do macchina da scrivere. Swoistemu stopniowaniu ulegają następujące po sobie asocjacje związane z oboma wyrazami. Najpierw pojawia się un arto di ferro, 'żelazna kończyna', kojarząca się i ze światem organizmów żywych, i ze światem maszyn (nomenklatura techniczna często posługuje się personifikacją lub podobieństwem, a więc metaforyką codzienną, z gatunku root metaphor opisywanych przez Lakoffa i Johnsona ${ }^{16}$ w takich określeniach, jak np. 'ramię dźwigu', 'żuraw', 'kolanko pod zlewem'). Później wymienione zostaje un ordigno, a więc to, co zwykle nazywamy „zmyślnym mechanizmem" lub narzędziem tak skomplikowanym, że trudnym w obsłudze lub wywołującym zaniepokojenie użytkownika, oraz, w odrębnym wersie, choć w sekwencji równorzędnych wyliczeń, znów wyobrażenie przywodzące na myśl nie maszynerię, lecz narząd drapieżnej istoty żywej, podlegający jednak działaniu rozumu: un artiglio che ubbidiva al cervello. Klawisze maszyny do pisania, połączone systemem dźwigni, ukazywane są - zgodnie z regułą poznawania nieznanego za pomocą odniesień do realiów świata fizycznego ${ }^{17}$ - jako pazury zwierzęcia, posłusznego rozkazom mózgu, a jednocześnie zachowującego cechy urządzenia mechanicznego. Tak postrzegana maszyna do pisania okazuje się artefaktem z pogranicza „przyrody ożywionej” i wytworów techniki, narzędziem bezpośrednio włączonym w proces twórczy, a wręcz jednym z mediów tego procesu. Opisowa, graficznie wyróżniająca się dłuższymi, wzorowanymi na tradycji epickiej, a wewnętrznie wyznaczona dwoma zdaniami rozpoczynającymi się od czasowników w czasie przeszłym niedokonanym (era i rimandava) część wiersza urywa się w tym miejscu. Czas przeszły podkreśla anachroniczność

(cf. A. Ginsberg, Mescaline, w: Poems for Millenium. The University of California Book of Modern \& Postmodern Poetry, t. 2: From Postwar to Millenium, red. J. Rothenberg, P. Joris, Berkeley-Los Angeles-London 1998, s. 279).

${ }^{15}$ Cf. [hasło:] Ariete, w: G. Devoto, G. C. Oli, op. cit., s. 131; N. Zingarelli, op. cit.

${ }^{16}$ Vide G. Lakoff, M. Johnson, Metafory w naszym życiu, tłum. T. P. Krzeszowski, Warszawa 1988.

${ }^{17}$ Cf. A. Hultzsch, Architecture, Travellers and Writers. Constructing Histories of Perception 1640-1950, Rome 2014, s. 129-132. 
maszyny do pisania i jej przynależność do sfery artefaktów minionych. Przeskok od imperfetto do presente jest integralnym składnikiem metafory przełomu, który dokonał się również na poziomie świadomości: maszyna do pisania może stać się metaforą przeszłości, ponieważ odbiorca przyswoił już system obrazów i przenośni związanych z obecnością komputera w codziennej przestrzeni ${ }^{18}$, również jako pojęcie macchina per scrivere przemieściła się w obszar skojarzeń odbieranych jako historyczne.

Dwa krótkie wersy, które następują bezpośrednio po niej, mogłyby samodzielnie funkcjonować jako sentencja ogólna („Eppure non ha senso / rimpiangere il passato” - „A mimo to nie ma sensu / żałować przeszłości”), ale uzupełnia je dalsza część zdania, również rozbitego na dwa człony, wzmacniająca wydźwięk generalizującej refleksji, która mówi nie o cezurach, ale o tym, co wydaje się niezmienną regułą. Sugeruje to nie tylko powrót do czasu teraźniejszego, ale przede wszystkim bezosobowy charakter zdania głównego i równoważnikowych dopełnień (rimpiangere il passato i provare nostalgia - 'tęsknić, odczuwać nostalgię'). Z każdego prawidła wydaje się wyrastać następne ${ }^{19}$ : pozbawiony sensu jest nie tylko żal za przeszłością, ale również tęsknota - doprecyzowana odrębnym zdaniem, wyeksponowanym za pomocą przerzutni: ,per quello che / crediamo di essere stati”. Niełatwy do oddania w równie skondensowanej i bogatej w znaczenia fragment. Dosłownie należałoby go rozumieć 'za tym, czym sądzimy/uważamy/wydaje nam się, że byliśmy'; istotne jest tu przenikanie się aktualnego stanu rzeczy (sądzimy, wydaje nam się - w tym przypadku konieczne jest wprowadzenie zaimka osobowego, co - w stosunku do tekstu

${ }^{18}$ Cf. J. R. Hobbs, Literature and Cognition, Stanford 1990, s. 81.

${ }^{19} \mathrm{~W}$ tym miejscu interpretator-erudyta powinien zwalczyć $\mathrm{w}$ sobie pokusę pójścia za falą skojarzeń historycznoliterackich i zrezygnować z powiązania utworu Aneddy z barokową tradycją wiersza-maszyny, poezji permutacyjnej. Budowa Macchiny nie opiera się na formule kombinatorycznej, która pozwalałaby w nieskończoność manipulować frazami i produkować z nich logiczne twierdzenia (cf. A. Pająk, Islamskie ogrody i barokowe teksty-maszyny. Porady dla hipertekstowych ogrodników. Brama stów, cz. 7, „Techsty. Magazyn” 2008, nr 4, http://www.techsty. art.pl/magazyn4/artykuly/pajak/brama_slow07.html [d.d. 19.04.2020]; szerzej na ten temat vide M. Pieczyński, Kirke, Proteusz $i$ „Lutnia rozstrojona”. O poezji eksperymentalnej późnego baroku $w$ świetle wypowiedzi teoretycznych, Warszawa 2013). Można by się zastanawiać, czy stosowanie kryptocytatów z Tacyta w innych wierszach z cyklu, np. w Annales, nie stanowi technicznego zapożyczenia $\mathrm{z}$ tej odmiany literatury barokowej, jednak koncepcja całego tomiku, oparta na świadomej stylizacji na starożytną historiografię, taką ewentualność wyklucza. W zbiorze Historiae dokonuje się bowiem świadome pominięcie tradycji literackich, jakie dzielą współczesność od antyku, swoisty przeskok ponad konwencjami ekspresji artystycznej i podziałami gatunkowymi. Powrót do języka beznamiętnej (czyli: nielirycznej i z pewnością niebarokowej) relacji gwarantuje, zgodnie z koncepcją cyklu, możliwość ujrzenia zjawisk jako powtarzalnych, a więc stanowiących normę (zasadę) dziejów ludzkości, ale warunkiem, by się to dokonało, jest aktywne działanie Ingardenowskiego ,podmiotu czynności twórczych” - rejestrującego i zmiany, i fenomeny powracające. 
oryginalnego - ujmuje przesłaniu zwięzłości) i sytuacji minionej: przeszłość nie stanowi wartości obiektywnej, ale jest głęboko nacechowana subiektywnością momentu, w którym zostaje przywołana. Ukierunkowana w przeszłość introspekcja nie przynosi obiektywnego obrazu jednostki snującej refleksję, ale wrażenie, indywidualne przekonanie, wyobrażenie tożsamości zdeterminowane perspektywą patrzącego „tu i teraz”, w przestrzeni czasu teraźniejszego. Postrzegane przez filtr pamięci (bezokolicznik passato prossimo) i bieżącego momentu (crediamo) istnienie okazuje się kategorią płynną, pozbawioną stabilności - tak samo jak płynna jest tożsamość człowieka, rozciągnięta pomiędzy czasem „pisania na maszynie” i „stukania w klawiaturę komputera”.

Efekt podważenia obiektywnej wartości czasu fizykalnego przez zastosowanie gry czasem gramatycznym zachowany zostaje w końcowej partii utworu, gdzie powraca epicki tok zdania, paradoksalnie mieszczącego się tutaj w przestrzeni jednego wersu, i pojawia się kolejna prawda ogólna, oparta na niepotwierdzonej naukowo, lecz popularnej i chętnie we Włoszech cytowanej teorii starzenia się komórek ${ }^{20}$, w myśl której „Ogni sette anni si rinnovano le cellule” („co siedem lat odnawiają się komórki”). Przywołany werset można uznać za kryptocytat $\mathrm{z}$ jednego $\mathrm{z}$ popularnych poradników psychologicznych ${ }^{21}$, jednak w utworze Aneddy zanika typowa dla podobnych twierdzeń banalność. Odwołanie do biologii służy wzmocnieniu wcześniejszych obrazów, przede wszystkim zaś potwierdza koncepcję nieprzystawalności posiadanego w danym momencie przekonania o sobie samym do stanu faktycznego. Metafora „komórkowa” stanowi preludium do refleksji na temat nieodwracalnej różnicy między przeszłością i teraźniejszością, ujętej w formę kolejnej sentencji: „adesso siamo chi non eravamo". Znów pojawia się konstrukcja oporna pod względem translatorskim, bo polszczyzna chciałaby tu zapewne najpierw zobaczyć zdanie przeczące, a potem twierdzące: 'nie jesteśmy tym, kim byliśmy', jednak nie byłoby to chyba zgodne z wymową tekstu wyjściowego, w którym akcent pada na „teraz”, a obserwacja prowadzona jest z punktu widzenia ,ja” zbiorowego, którego podstawową cechą jest „bycie-tu-i-teraz”, w opozycji do przeszłości, która jest „nie-byciem-tu-i-teraz” (dosłownie: 'teraz jesteśmy kimś, kim nie byliśmy'). Zasadą istnienia człowieka okazuje się zmienność (dwupoziomowa, dotycząca

${ }^{20}$ Cf. J. Rofidal, Dō-in. Energia, serenità e salute, tłum. S. Bonarelli, Roma 2001, s. 94; V. G., Ogni 7 anni tutte le cellule del nostro corpo si rinnovano, 10.02.2016, https://www.anasitalia. org/ogni-7-anni-tutte-le-cellule-del-nostro-corpo-si-rinnovano/ (d.d. 30.03.2020); M. Świderska, Obawy zwiazane ze starością, „Pedagogika Rodziny” 2015, nr 5(3), s. 140.

${ }^{21}$ Przykładowo: „Sappiamo inoltre che ogni sette anni le cellule dell'organismo si rinnovano totalmente, eccezione fatta per le cellule nervose" [Wiadomo ponadto, że co siedem lat komórki organizmu całkowicie się odnawiają, wyjątek stanowią komórki nerwowe, tłum. i podkr. O.P.], J. Spinetta, L'uomo nuovo. Iniziazione nell'era dell'Acquario, tłum. G. Campioni, M. Ponti, Roma 1993, s. 135. 
sposobu postrzegania samego siebie, i ontologiczna, związana $\mathrm{z}$ naturalnym procesem upływu czasu i jego konsekwencjami). Z tej zmienności (ze względu na brak zdefiniowanych cezur i płynność procesu starzenia się, którego kolejne fazy wyznacza pojawianie się nowych narzędzi, służących do wykonywania tych samych czynności: maszynę do pisania zastępuje komputer, skomplikowaną i widoczną maszynerię, gwarantującą działanie klawiszy - niewidoczny procesor) człowiek nie w pełni zdaje sobie sprawę.

W zamykających utwór wersach dominują czasowniki w pierwszej osobie liczby mnogiej (dimentichiamo - 'zapominamy', restiamo - 'zostajemy'). Ta forma nadaje angażujący charakter twierdzeniom ogólnym: dzięki pluralis odbiorca staje się podmiotem mówiącym wiersza. Życie - za pomocą imiesłowu przysłówkowego ukazane jako proces ciągły - w świetle czasowników osobowych okazuje się również czasem nieświadomości $\mathrm{i}$, jak wynika $\mathrm{z}$ idiomu restare in carica, „przejściowego zatrudnienia”. Zaimek rzeczowny lo (w zwrocie lo dimentichiamo 'zapominamy o tym', 'zapominamy to' lub nawet 'zapominamy, że') jest kolejnym nośnikiem niejednoznaczności pozornie prostego przekazu Aneddy, może bowiem odnosić się zarówno do zdań wcześniejszych (czyli refleksji nad cyklicznością odnowy komórkowej i niezasadnością wspominania i rozpamiętywania tego, co minione), jak do końcowej frazy: restiamo in carica. W przekładzie należy uwzględnić nie tylko wspomnianą niejednoznaczność zaimka, ale również wziąć pod uwagę oszczędność składniową oryginału. Zmusza to tłumacza do poszukiwania rozwiązania alternatywnego dla konstrukcji dopełnieniowej typu „zapominamy o tym, że”, a także do podjęcia jednoznacznej decyzji co do sposobu interpretacji końcowego obrazu. Wyrażenie restiamo in carica per poco, zaczerpnięte $\mathrm{z}$ języka potocznego, jest również silnie nacechowane metaforycznie. Po pierwsze, dlatego że jego rdzeń stanowi „codzienna” przenośnia zbudowana wokół rzeczownika carica, który sam w sobie jest wieloznaczny (jego sensy oscylują od dosłownie rozumianego zadania lub zajęcia zleconego, obowiązku lub stanowiska w pracy, przez prozaiczny ładunek (towaru) po jego odmianę elektryczną i emocjonalną, a nawet wewnętrzną gotowość do czynu $^{22}$ ). Po drugie, z racji kontekstu, który wymusza figuratywną interpretację zwrotu językowego opartego na metaforze. W jego świetle główną cechą jakiejkolwiek ludzkiej aktywności wydaje się jej temporalność ('krótko jesteśmy czynni', można by sparafrazować ostatni wers utworu). Język polski przynosi tutaj dodatkowe możliwości interpretacyjne, związane ze znaczeniem zwrotu „Zajmować stanowisko”, który może posłużyć za ekwiwalent oryginalnego restare in carica. „Zajmować stanowisko” znaczy bowiem nie tylko 'pełnić określoną

${ }^{22}$ Cf. [hasło:] Carica, w: G. Devoto, G. C. Oli, op. cit., s. 333; N. Zingarelli, op. cit. (Versione 1.45, iPhone). 
funkcję zawodową', ale również 'wyrażać, głosić opinię'. Zastosowanie pierwszej osoby liczby mnogiej czasowników, wokół których konstruowana jest konkluzja utworu, powoduje, że odbiorca wiersza Aneddy z obserwatora i czytelnika, na chłodno percypującego serię prawd ujętych we wcześniejszych linijkach, przemienia się $\mathrm{w}$ myśliciela, zmuszonego do dokonania rewizji swoich przekonań ontologicznych i przyznania, że banalna prawda o ulotności i przemijalności dotyczy w równym stopniu rzeczy, jak istnień i pojęć.

Po polsku mógłby omawiany utwór brzmieć następująco:

Antonella Anedda, Maszyna

Palce na klawiaturze komputera stukają

- zaledwie nieco delikatniej -

niż kiedyś maszyna do pisania.

Ładnie się nazywała: maszyna, jeszcze lepiej,

kiedy bez $s z$ staje się machiną.

Rusztowaniem dla boga albo oblężenia, taranem, by obalać mury.

Pokazywała ramiona z żelaza, narzędzia

i szpony podległe działaniu rozumu.

A przecież nie ma sensu

żałować przeszłości,

tęsknić za tym, czym

zdaje się nam, że byliśmy.

Co siedem lat odnawiają się komórki:

jesteśmy teraz tym, kim nie byliśmy.

Za życia także - to zapominamy -

tylko na chwilę zajmujemy stanowisko.

Wiersz Macchina z tomiku Historiae stanowi wyraz dojrzałej poetyki Aneddy, którą od dawna cechuje, zgodnie z obserwacjami Nivy Lorenzini, „fotograficzna przenikliwość ujęcia" w połączeniu z całkowitym ogołoceniem emocjonalnym ${ }^{23}$. W utworze Aneddy nośnikiem napięcia są nadal przedmioty, tym razem przywołane na zasadzie synekdochy, w postaci swych reprezentatywnych części składowych: klawisza maszyny do pisania, komputerowej klawiatury. W kontekście cyklu, którego tytuł nawiązuje do problematyki relacjonowania i utrwalania tego, co minęło, obraz komputera stanowi wyraźną wskazówkę interpretacyjną, gdyż tradycyjnie - jak wskazuje Douwe Draaisma - wywołuje skojarzenia powiązane „Z polem semantycznym pamięci” ${ }^{24}$.

${ }^{23}$ Cf. N. Lorenzini, Le parole esposte. Fotostoria della poesia italiana del Novecento, Milano 2002, s. $160-161$.

${ }^{24}$ Cf. D. Draaisma, Machina metafor. Historia pamięci, thum. R. Pucek, Warszawa 2009, s. $240-241$. 
W wierszu Aneddy ich geometryczna sieć w zaskakujący sposób odsłania proces upływu czasu i wyznacza jego kolejne etapy, których symbolem są artefakty o zacierającej się stopniowo funkcji.

Otwarte pozostaje pytanie o to, czym jest tytułowa, pozbawiona rodzajnika (czyli o programowo zaakcentowanej wieloznaczności) Macchina. Czy rzeczywiście w wierszu Antonelli Aneddy chodzi o narzędzie służące do pisania, a więc służebne wobec każdego aktu utrwalania tego, co przemijające, czy o człowieka, który - jak wytworzone przez niego instrumentarium przedmiotów użytecznych podlega procesom zużycia i wyczerpania i może być zastąpiony kolejną, doskonalszą wersją urządzenia, przede wszystkim zaś jest istotą śmiertelną?25

${ }^{25}$ Postrzegany z perspektywy historii idei utwór Aneddy wpisuje się w nurt refleksji nawiązujących do mechanicystycznej koncepcji człowieka w jej odmianie literackiej i filozoficznej. W tych teoriach „organizm ludzki zestawia się i porównuje z maszynami”, a wraz z upływem czasu obraz człowieka jako maszyny ewoluuje „od maszyny hydrauliczno-mechanicznej do komputera kwantowego" (M. Wnuk, Człowiek jako reprodukujący się mechanizm, w: Dusza. Umyst. Ciało. Spór o jedność bytową człowieka, red. A. Maryniarczyk SDB, K. Stępień, Lublin 2007, s. 195, 201). Literackie dzieje tego wątku zasługiwałyby na odrębne potraktowanie, ograniczam się do przypomnienia kilku istotniejszych jego aspektów. O ile początki mechanicyzmu sięgają starożytności (z biblijną oraz grecko-rzymską ideą człowieka ulepionego z gliny, mitami Talosa z Krety i Pandory u Greków i Rzymian) i zadomowione są dobrze w epoce chrześcijaństwa (legenda Golema w tradycji kabalistycznej - a do piśmiennictwa przeniesiona dopiero w 1915 r. przez Gustava Meyrinka), o tyle jego założenia filozoficzne formułowane są od wieku XVII, a rozkwitają w XVIII i XIX stuleciu (vide M. Heller, J. Życiński, Wszechświat maszyna czy myśl? Filozofia mechanicyzmu: powstanie - rozwój - upadek, Kraków 1988), przechodząc stopniowo od filozofii ku literaturze (natomiast, jak podkreśla Marian Wnuk, „myślenie w kategoriach mechanizmów” stanowi dziś jedną z metod postępowania naukowego w wielu nowych dziedzinach badań: biomechanice, bionice, biocybernetyce, cf. M. Wnuk, op. cit., s. 179-182). Zanim Julien Offray de La Mettrie (1709-1751) stwierdził, że „ciało ludzkie jest maszyną, która nakręca sama swoje własne sprężyny; jest to żywy obraz perpetuum mobile”, uznawszy przy tym, że dusza (najważniejsza ze sprężyn) jest „częścią materialną mózgu” (J. O. de La Mettrie, Człowiek-maszyna, tłum. S. Rudniański, Warszawa 1984, s. 22, 74), podobne (i również z ducha materializmu wyrastające) tezy formułował sto lat wcześniej Thomas Hobbes (1588-1679), który w traktacie Lewiatan, czyli materii, formy i władzy państwa kościelnego i świeckiego rozważał, czy możliwe jest stworzenie „sztucznego zwierzęcia”, i dochodził do wniosku, że jeśli życie polega na „ruchu członków” inspirowanych impulsem płynącym z wnętrza ciała, to „wszelkie automaty (maszyny, które poruszają się z pomocą sprężyn i kół, jak zegar) mają sztuczne życie" (Th. Hobbes, Lewiatan, czyli materia, forma $i$ władza państwa kościelnego i świeckiego, tłum. C. Znamierowski, Warszawa 1954, s. 5). Literatura powołuje do życia takie twory, jak Goetheański homunculus (bardziej „wyhodowany” niż mechaniczny), ożywiona kukła z ludzkich szczątków, jaką jest stworzony przez Frankensteina potwór w powieści Mary Shelley, demoniczny Dziadek do Orzechów (nb. podarunek zegarmistrza) w powiastce E. T. A. Hoffmanna albo, na gruncie włoskim, niemniej niepokojący, choć z pozoru niewinny Pinocchio Carla Collodiego. Skoro mowa o Włoszech, warto podkreślić, że filozofia Hobbesa stanowiła jedno ze źródeł inspiracji dla Giacoma Leopardiego, który w swoich Dziełkach moralnych ukuł ironiczną koncepcję zastąpienia ułomnych z natury i niedoskonałych ludzi maszynami (pierwsza z nich miała pełnić funkcje „un amico il quale non biasimi e non motteggi l'amico assente” „takiego przyjaciela, który by nie obmawiał i nie wyśmiewał przyjaciela pod jego nieobecność”; 
Jedno jest pewne: zastąpienie maszyny do pisania klawiaturą komputera i wirtualną stronicą otwartą na ekranie stanowi znak czasu, wyznacza granicę między dwiema epokami: słowa istniejącego materialnie, w postaci odciśniętego na papierze śladu tuszu, i słowa wirtualnego ${ }^{26}$, istniejącego w formie cyfrowego kodu, który umownie przyjmuje tradycyjny kształt liter. Pewne jest więc również to, że trwałe jest nie narzędzie, ale to, co za jego pomoca powstaje. Wartość tekstu nie zależy od tego, czy został wystukany na maszynie, czy zapisany na komputerze, ale na jego zdolności przekazywania treści uniwersalnych oraz prawd, które potrafią przykuć uwagę odbiorcy niezależnie od tego, czy mierzy czas wielością kulturowych zwrotów, czy wynalazków zmieniających strategie komunikacji i sposób postrzegania świata.

\section{Bibliografia}

Anedda, Antonella, Historiae, Torino 2018.

Boitani, Piero, Di Rocco, Emilia, Guida allo studio delle letterature comparate, Roma-Bari 2013, Kindle e-book.

Calandrone, Maria Grazia, Antonella Anedda chiara come una pietra, http://www. mariagraziacalandrone.it/index.php?option $=$ com_content $\&$ view $=$ article $\&$ id $=604$ : antonella-anedda-historia\&catid $=18 \&$ Itemid $=162$ (d.d. 30.03.2020).

Cioran, Juan-Eduardo, Stownik symboli, tłum. I. Kania, Kraków 2006.

Devoto, Giacomo, Oli, Gian Carlo, Il dizionario della lingua italiana, Firenze 1995.

Draaisma, Douwe, Machina metafor. Historia pamięci, tłum. R. Pucek, Warszawa 2009. Gardiner, Eileen, Musto, Ronald G., The Digital Humanities. A Primer for Students and Scholars, Cambridge 2015.

cf. G. Leopardi, Proposta di premi fatta dall'Accademia dei Sillografi, w: idem, Operette morali, Santarcangelo di Romagna 2004, s. 20 (G. Leopardi, Konkurs ogłoszony przez Akademię Sylografów, w: idem, Dzietka moralne, tłum. S. Kasprzysiak, Kraków 1979, s. 31). Za swoisty wariant koncepcji człowieka-maszyny należałoby zapewne uznać także mit Pigmaliona oraz nawiązujące do niego przewrotnie dziewiętnastowieczne historie literackie o żyjących lub ożywionych posagach: Wenus z Ille Prospera Merimée, Marmurowego fauna Nathaniela Hawthorne'a (cf. O. Płaszczewska, Romantyczne Galatee. Inkarnacje i metamorfozy dziet plastycznych w literaturze (Merimée - Hawthorne - Żmichowska), w: Powinowactwa sztuk w kulturze oświecenia i romantyzmu, red. A. Seweryn, M. Kulesza-Gierat, Lublin 2012, s. 303-318) albo Posag z marmuru Josepha von Eichendorffa. Macchina Antonelli Aneddy potwierdza tezy tych badaczy, którzy głoszą, że „metafora człowieka jako maszyny jest nadal heurystycznie płodna” (cf. M. Wnuk, op. cit., s. 203), a jej symbolika wykroczyła poza pierwotny obszar znaczeń związanych „z wchłanianiem, trawieniem i reprodukcją" (cf. J.-E. Cioran, Maszyny, w: idem, Stownik symboli, thum. I. Kania, Kraków 2006, s. 249).

${ }^{26}$ Nawet z perspektywy kognitywistów zajmujących się problematyką języków komputerowych i przekładu automatycznego, maszynowego, słowo postrzegane jest jako zjawisko z wymiaru misterium: „Hence, we have not stripped words of their mysterious quality, but rather translated the mystery into the mystery of choosing the right set of interferences", wyznawał już w $1983 \mathrm{r}$. Jerry R. Hobbs, cf. J. R. Hobbs, op. cit., s. 58. 
Ginsberg, Allan, Mescaline, w: Poems for Millenium. The University of California Book of Modern \& Postmodern Poetry, t. 2: From Postwar to Millenium, red. J. Rothenberg, P. Joris, Berkeley-Los Angeles-London 1998.

G., V., Ogni 7 anni tutte le cellule del nostro corpo si rinnovano, 10.02.2016, https://www.anasitalia.org/ogni-7-anni-tutte-le-cellule-del-nostro-corpo-si-rinnovano/ (d.d. 30.03.2020).

Heller, Michał, Życiński, Józef, Wszechświat - maszyna czy myśl? Filozofia mechanicyzmu: powstanie - rozwój - upadek, Kraków 1988.

Heuvel van den, Charles, Historical Roots of Information Sciences and the Making of e-Humanities, w: Making of Humanities, t. 3: Modern Humanities, red. R. Bod, J. Maat, Th. Weststeijn, Amsterdam 2014.

Hobbes, Thomas, Lewiatan, czyli materia, forma i wtadza państwa kościelnego i świeckiego, tłum. C. Znamierowski, Warszawa 1954.

Hobbs, Jerry R., Literature and Cognition, Stanford 1990.

Hultzsch, Anne, Architecture, Travellers and Writers. Constructing Histories of Perception 1640-1950, Rome 2014.

Lakoff, George, Johnson, Mark, Metafory w naszym życiu, tłum. T. P. Krzeszowski, Warszawa 1988.

La Mettrie de, Julien Offray, Człowiek-maszyna, tłum. S. Rudniański, Warszawa 1984.

Leopardi, Giacomo, Dziełka moralne, tłum. S. Kasprzysiak, Kraków 1979.

Leopardi, Giacomo, Operette morali, Santarcangelo di Romagna 2004.

Lorenzini, Niva, Le parole esposte. Fotostoria della poesia italiana del Novecento, Milano 2002.

McHale, Brian, Poezja jako proteza, thum. A. Rogulska, „Techsty. Magazyn” 2014, nr 9 (1), http://www.techsty.art.pl/m9/b_mchale_poezja_jako_proteza.html (d.d. 15.04.2020).

Mikołajewski, Jarosław, Rzymska komedia, Warszawa 2011.

Milani, Giuseppe, Pepe, Mario, Dizionario di arte e letteratura. Teorie. Movimenti. Generi. Tecniche. Materiali, Milano 2003.

Pająk, Andrzej, Islamskie ogrody i barokowe teksty-maszyny. Porady dla hipertekstowych ogrodników. Brama słów, cz. 7, „Techsty. Magazyn” 2008, nr 4, http://www.techsty.art.pl/ magazyn4/artykuly/pajak/brama_slow07.html (d.d. 19.04.2020).

Pieczyński, Maciej, Kirke, Proteusz i „Lutnia rozstrojona”. O poezji eksperymentalnej polskiego baroku w świetle wypowiedzi teoretycznych, Warszawa 2013.

Płaszczewska, Olga, Romantyczne Galatee. Inkarnacje i metamorfozy dziet plastycznych w literaturze (Merimée - Hawthorne - Żmichowska), w: Powinowactwa sztuk w kulturze oświecenia i romantyzmu, red. A. Seweryn, M. Kulesza-Gierat, Lublin 2012.

Puchalska, Iwona, Maszyny muzyczne, maszyny poetyczne: urządzenia i nośniki fonograficzne $w$ wierszach poetów polskich $X X$ wieku, ,Rocznik Komparatystyczny/Comparative Yearbook/Komparatistisches Jahrbuch" 2016, nr 7.

Rofidal, Jean, Dō-in. Energia, serenità e salute, tłum. S. Bonarelli, Roma 2001.

Sinfonico, Damiano, Poesia come sintesi dei saperi. Historiae di Anedda, 13.10.2018, https://www.labalenabianca.com/2018/11/13/21440/ (d.d. 30.03.2020).

Spinetta, Jean, L'uomo nuovo. Iniziazione nell'era dell'Acquario, tłum. G. Campioni, M. Ponti, Roma 1993. 
Świderska, Mariola, Obawy zwiazane ze starościa, „Pedagogika Rodziny” 2015, nr 5(3). Testa, Enrico, Antonella Anedda, w: Dopo la lirica. Poeti italiani 1960-2000, red. idem, Torino 2005.

Wnuk, Marian, Człowiek jako reprodukujacy się mechanizm, w: Dusza. Umyst. Ciało. Spór o jedność bytowa człowieka, red. A. Maryniarczyk SDB, K. Stępień, Lublin 2007.

W szczelinie między czuwaniem a snem. Sto dziesięć wierszy włoskich poetów wspótczesnych, tłum. J. Mikołajewski, Kraków-Budapeszt-Syrakuzy 2019.

Zingarelli, Nicola, Lo Zingarelli 2019. Vocabolario della lingua italiana, red. M. Canella, B. Lazzarini, Bologna 2018 (Versione 1.45, iPhone).

Olga PŁaszczewska, dr hab., prof. UJ, historyk literatury i komparatystka, profesor w Katedrze Komparatystyki Literackiej Wydziału Polonistyki Uniwersytetu Jagiellońskiego, tłumaczka, z wykształcenia polonistka i italianistka. Autorka licznych prac z literatury porównawczej, m.in. książek: Btazen i błazeństwo $w$ dramacie romantycznym (Kraków 2002), Wizja Włoch w polskiej i francuskiej literaturze okresu romantyzmu (Kraków 2003), Włoskie przekłady dzieł Juliusza Stowackiego (Kraków 2004), Przestrzenie komparatystyki - italianizm (Kraków 2010), Wtoskie divertimento. Szkice komparatystyczne (2017). Redaktorka i współredaktorka wielu tomów zbiorowych z komparatystyki i historii literatury polskiej, członek redakcji dwumiesięcznika „Arcana”. 